\section{Titanium Carbide: Synthesis, Properties and Applications}

\author{
Mohsen Mhadhbi ${ }^{\mathrm{a}}$ and Miloud Driss ${ }^{\mathrm{b}}$ \\ ${ }^{a}$ Laboratory of Useful Materials, National Institute of Research and Physical-chemical Analysis, Technopole, SidiThabet 2020 \\ Ariana, Tunisia \\ ${ }^{b}$ Laboratory of Sciences and Technology of Water, University of Mascara, 29000, Algeria.
}

\section{Keywords}

Titanium carbide,

Properties,

Microstructure,

Applications,

Nanostrcuture

\begin{abstract}
Composite materials are known in various forms. The two distinctive constituents of these composite materials are the matrix material and the reinforcement material. A variety of materials are used as reinforcing material in composites titanium carbide (TiC). TiC acquired considerable attention because of its unique properties, which make it very attractive for advanced applications. The current review summarizes various synthesis techniques to produce TiC nanocomposite and highlights the major industrial applications of TiC. It was found that for certain techniques, the TiC powder has been synthesized directly, with different shapes and sizes, within a relatively very short time by eliminating a number of intermediate processes. However, this review deals with the detailed literature survey carried out on the preparation of titanium carbide powder, and also covers analyzes the results from the experiments conducted on the preparation of powder by the works of several researchers. Therefore, in-depth conclusions have been done on the research processes that are being carried out on improving the properties of $\mathrm{TiC}$ reinforced composites.
\end{abstract}

\section{Introduction}

For a decade, titanium carbide (TiC) attracted considerable attentions due to its special characteristics like surface, shape, size, and interface. Among the ceramic materials, $\mathrm{TiC}$ is a well-known material reinforcing agent in metal composites due to its high melting point, elastic modulus, high Vickers hardness, low density, high flexure strength, good thermal conductivity, high resistance to corrosion and oxidation, and high thermal shock resistance. In recent years, significant research activities were focused on the synthesis of $\mathrm{TiC}$ nanoceramic. Thus, throughout all of those developments, TiC always reveals special morphology to follow the further applications.

However, TiC can be synthesized using several methods, which will be discussed in depth in this review. Indeed, methods like traditional method, chemical vapor deposition (CVD), laser igniting selfpropagating high-temperature synthesis (LISHS), sol-gel, selfpropagating high-temperature synthesis (SHS), mechanical alloying (MA), etc will be presented in details.

Titanium carbide has been widely used for high-temperature applications, such as aerospace, cutting tools, electronics, and chemicals. It is also used as reinforced particles in composites and hardening phase of super-alloys.

In this review paper, we will focus on the influence of titanium carbide synthesis methods on their properties and applications.

\section{Structure of titanium carbide}

Titanium carbide, with chemical formula TiC, crystallizes in the cubic system: $\mathrm{NaCl}$ type with space group $\operatorname{Fm} 3 m(\mathrm{Z}=4)$. The lattice constant is $\mathrm{a}=0.4327 \mathrm{~nm}$. Ti atoms occupy the origin positions $(0,0,0)$, however, $\mathrm{C}$ atoms are located in $(1 / 2,1 / 2,1 / 2)$ positions. Ti and $\mathrm{C}$ atoms are octahedrally coordinated with each other; consequently, $\mathrm{Ti}_{6} \mathrm{C}$ octahedra share edges [1]. Fig. 1 shows the schematic structure of titanium carbide. As can be seen, Fig.1a illustrates the typical crystal structure of TiC [2]. C atoms occupy the octahedral positions. Thus, if viewed along the direction perpendicular to the planes, $\mathrm{Ti}$ and $\mathrm{C}$ atoms form a hexagonal shape, as presented in Fig.1b [3].

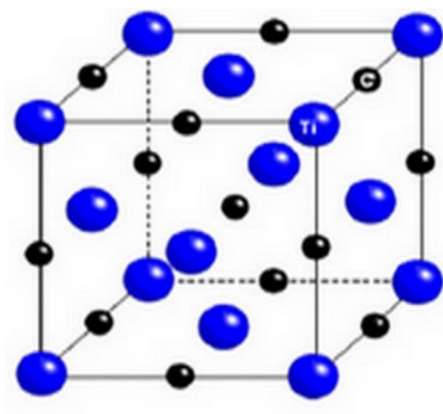

(a)

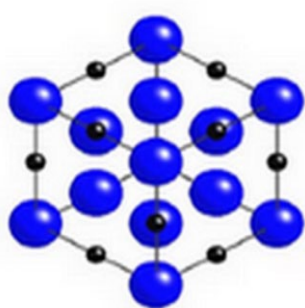

(b)
Figure 1. (a) Crystal structure of TiC, and (b) projection of Ti-C atoms along direction [2]. The smaller and black atoms are $\mathrm{C}$ atoms.

\section{Summary of properties of titanium carbide}

Titanium carbide particles are effectively used as a reinforcement phase in composites due to its superior mechanical properties, unique electrical properties, and high temperature strength. Fine grained TiC can improve yield strength of the composites through dispersion and grain size mechanisms and improve toughness by hindering crack propagation [4, 5]. Table 1 summarizes the electrical, mechanical, chemical, and thermal properties of titanium carbide at room temperature [6-10]. 
Table 1. Properties of TiC at room temperature

\begin{tabular}{|c|c|}
\hline Electrical properties & \\
\hline Molecular Weight & 59.91 \\
\hline Density (g. $\left.\mathrm{cm}^{-3}\right)$ & 4.91 \\
\hline Electrical conductivity $\left(10^{6}\right.$ S. $\left.\mathrm{cm}^{-1}\right)$ & 30 \\
\hline Electrical resistivity ( $\mu \Omega . \mathrm{cm})$ & 68 \\
\hline Hall constant $\left(10^{-4} \mathrm{~cm}^{3} /\right.$ A.s $)$ & -15 \\
\hline Magnetic susceptibility $\left(10^{-6} \mathrm{emu} / \mathrm{mol}\right)$ & -7.5 \\
\hline Superconductive transition temperature (K) & 1.15 \\
\hline \multicolumn{2}{|l|}{ Mechanical properties } \\
\hline Vickers hardness (GPa) & $28-35$ \\
\hline Young's modulus (GPa) & $410-510$ \\
\hline Shear modulus (GPa) & 186 \\
\hline Flexure strength (MPa) & $240-390$ \\
\hline Poisson's ratio & 0.191 \\
\hline \multicolumn{2}{|l|}{ Chemical properties } \\
\hline Chemical symbol & TiC \\
\hline Color & Silver gray \\
\hline Electronic configuration & $\begin{array}{c}\text { Ti: } \\
{[\mathrm{Ar}] 3 \mathrm{~d}^{2} 4 \mathrm{~s}^{2}} \\
\mathrm{C}:[\mathrm{He}] 2 \mathrm{~s}^{2} 2 \mathrm{p}^{2}\end{array}$ \\
\hline Chemical composition (\%) & $\begin{array}{c}\text { Ti content } \\
(79.95) \\
\text { C content } \\
(20.05)\end{array}$ \\
\hline Structure & $\begin{array}{c}\text { Cubic B1 } \\
(\mathrm{NaCl})\end{array}$ \\
\hline Lattice parameter (nm) & 0.4328 \\
\hline Space group & $F m 3 m$ \\
\hline Pearson symbol & CF8 \\
\hline \multicolumn{2}{|l|}{ Thermal properties } \\
\hline Melting temperature $\left({ }^{\circ} \mathrm{C}\right)$ & 3067 \\
\hline Boiling temperature $\left({ }^{\circ} \mathrm{C}\right)$ & 4820 \\
\hline Thermal conductivity $\left({ }^{\circ} \mathrm{C}\right)$ & 21 \\
\hline Enthalpy of formation $\left(\mathrm{kJ} \cdot \mathrm{mol}^{-1}\right)$ & -184 \\
\hline Specific heat $(\mathrm{J} / \mathrm{mol} . \mathrm{K})$ & 33.8 \\
\hline Thermal expansion $\left(\times 10^{-6} /{ }^{\circ} \mathrm{C}\right)$ & 7.6 \\
\hline
\end{tabular}

\section{Phase diagram of titanium carbide}

Fig. 2 illustrates the binary phase diagram of Ti-C system [11]. The system consists of solids $\alpha-\mathrm{Ti}, \beta-\mathrm{Ti}$, and a refractory monocarbide (TiC). As we can see, two other phases are present: liquid (L) and graphite (C). Thus, the system represents two eutectic and one peritectoid at 1646,2776 , and $920^{\circ} \mathrm{C}$, respectively.

\section{Fabrication processes of titanium carbide}

Titanium carbide occurs in nature as a form of the very rare mineral khamrabaevite [(Ti,V,Fe)C]. Traditionally, TiC powders are commercially produced by the reaction of titanium dioxide and carbon in the temperature range of $1700-2300{ }^{\circ} \mathrm{C}$ for $10-24 \mathrm{~h}$ [12]. The synthesis of TiC powders by the carbothermal reduction demands a significant amount of energy. Thus, there have been several methods regarding synthesis of titanium carbide [13, 14]. Every approach has varying features of morphology, particle size and distribution, condition of agglomeration, chemical purity, and stoichiometry [4].

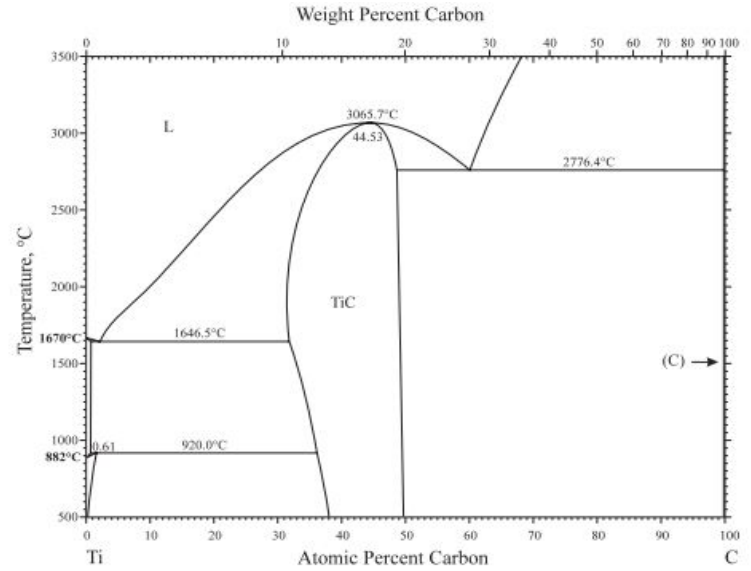

Figure 2. Ti-C phase diagram [11]

\subsection{Carbothermal reduction}

Carbothermal reduction is a sample and inexpensive process that produces large amounts of powder and makes use of inexpensive precursor materials. These reduction processes are basically carried out at high temperatures; hence they are known as carbothermal reduction process $[4,15]$. Almost all commercial productions primarily use a carbothermal reduction due to its low cost $[4,16]$. There is currently no commercial powder production process to synthesize submicron $\mathrm{TiC}$ powder [17]. $\mathrm{TiO}_{2}$ was used as a raw material on an industrial scale due to its low cost and easy availability which reduces the cost of production and makes the process economical. Furthermore, TiC powder was commercially produced primarily by the reduction of $\mathrm{TiO}_{2}$ by carbon, especially carbon black, in a temperature range $1700-2100{ }^{\circ} \mathrm{C}$ and long reaction times (10-24 h) [4, $18]$.

The chemical reaction in the carbothermal reduction is given by:

$\mathrm{TiO}_{2(\mathrm{~s})}+3 \mathrm{C}_{(\mathrm{s})} \otimes \mathrm{Ti}_{(\mathrm{s})}+2 \mathrm{CO}_{(\mathrm{g})}$

It has been proposed that this general equation consists of three reaction steps (Fig. 3) [19].

* Step I: In this first step, CO is formed by a solid-state reaction between the titanium dioxide $\left(\mathrm{TiO}_{2}\right)$ and carbon particles or by the destruction of oxygen-containing functional groups at the carbon surface, acts as a reducing agent, resulting in the formation of lower oxides $\left(\mathrm{TinO}_{2 \mathrm{n}-1}\right)$. At the end of this step, $\mathrm{Ti}_{3} \mathrm{O}_{5}$ or $\mathrm{Ti}_{2} \mathrm{O}_{3}$ oxide phase is formed, there is no incorporation of carbon into the oxide particles, and $\mathrm{CO}$ is regenerated by the immediate conversion of $\mathrm{CO}_{2}$ to $\mathrm{CO}$ on the solid carbon.

* Step II: In this intermediate step, cubic $\mathrm{TiC}_{\mathrm{x}} \mathrm{O}_{\mathrm{y}}$ is formed from $\mathrm{Ti}_{3} \mathrm{O}_{5}$ or $\mathrm{Ti}_{2} \mathrm{O}_{3}$ phase. Thus, $\mathrm{CO}$ acts as a reducing agent and simultaneously disproportionate at the surface, which is rich in lattice defects and which accommodates the incorporation of carbon into the crystal lattice. $\mathrm{CO}_{2}$ is generated and immediately converted to $\mathrm{CO}$ on the solid carbon. Therefore, the oxide particles are the precursors for the oxycarbide formed. The reaction rates of oxygen loss and carbon incorporation are not equal; consequently, the intermediate oxycarbide is sub-stoichiometric.

* Step III: In this final step, there will be a substitution of oxygen by carbon in $\mathrm{TiC}_{\mathrm{x}} \mathrm{O}_{\mathrm{y}}$. The mass transfer is realized by the same reaction mechanism as in reaction step II.

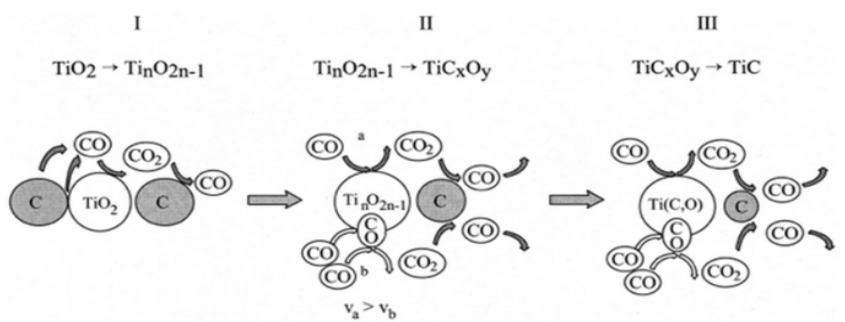

Figure 3. Schematic of the reaction mechanism of the carbothermal reduction of $\mathrm{TiO}_{2}[19]$ 
There have been many studies on the fabrication of $\mathrm{TiC}$ powders by carbothermal reduction. TiC nanoparticles were fabricated by carbothermal reduction of precursor gels. Thus, TiC nanopowders with the specific surface area of $30-200 \mathrm{~m}^{2} / \mathrm{g}$, and the crystallite size of 40-45 nm were obtained [20]. Morevover, titanium carbide allows new applications including various types of composite materials [2] The experimental results show that the samples have average sizes ranging within $30-40 \mathrm{~nm}$. There was other work regarding synthesis of TiC powders, with lattice parameter of $0.43631 \mathrm{~nm}$, using carbothermal reduction from $\mathrm{TiO}, \mathrm{C}$, and $\mathrm{Ti}$ metallic form [21].

Wei et al. (2011) [22] prepared homogeneous and fine TiC powders via carbothermal reduction at $15500^{\circ} \mathrm{C}$ for $4 \mathrm{~h}$ in a vacuum. In their study, the reduction of $\mathrm{TiO}_{2}$ by graphite was also investigated. Sarkar et al. (2009) [23] studied the carbothermal reduction of nano-rutile by amorphous carbon. They reported that TiC nanoparticles with crystallite size smaller than $100 \mathrm{~nm}$ are obtained. Similarly, Berger (1992) [24] investigated the mechanism and kinetics of TiC formation from eight starting mixtures, four titanium dioxide grades (three rutile grades with various grain sizes and one anatase grade), and two carbon blacks (one furnace black and one acetylene). It was found that the use of anatase has no accelerating effect on the reaction kinetics, while the grain size of the rutile grades has an effect only at high temperatures. It was also shown that the carbon black grades give no clear picture of the influence of their particle size and degree of graphitization.

Maitre et al. (2000) [25] investigated the role of some technological parameters during carburizing titanium dioxide from mixtures $\mathrm{TiO}_{2} / \mathrm{C}$. They concluded that the carburizing rate of $\mathrm{TiO}_{2}$ can be accelerated by using the fine $\mathrm{C}$ powders, and with an important gas flow for reducing the partial pressure of carbon monoxide in the reactor. In fact, high purety TiC material, with reasonable reaction times, was obtained. Chandra et al. (2009) [26] synthesized nano-TiC powder using carbothermal reduction of titanium gel precursor and carbon particles. Koc (1997) [27] found that fine particle size of TiC (0.1 - $0.3 \mu \mathrm{m}$ ), oxygen content of $0.57 \mathrm{wt} \%$ and lattice parameter of $0.4331 \mathrm{~nm}$, was obtained by carbothermal reduction of carbon-coated titania.

Preiss et al. (1999) [28] produed TiC powder, with finer particle size (1 $\mu \mathrm{m})$ and with lower oxygen content $(1.2-3.4 \mathrm{wt} \%)$, by using the carbothermal process from rutile and carbon black. Gotoh et al. (2001) [29] successfully synthesized TiC nanoparticle using carbotherma reduction from a composite of $\mathrm{TiO}_{2}$ nanoparticles and methylcellulose (organic polymer). Koc and Folmer (1997) [30] used carbothermal for the reduction of ultrafine titania powders. They concluded that high purity and nonagglomerated TiC powders, with finer particle size $(0.1$ $\mu \mathrm{m})$ and with lower oxygen content (0.6 wt\%), are obtained. Sen et al. (2010) [31] prepared fine TiC powders by carbothermal reduction of titania and charcoal at vacuum condition. They revealed that fine TiC powders (D50, $2.05 \mu \mathrm{m}$ ), with low impurities, were obtained at $1450^{\circ} \mathrm{C}$ for $8 \mathrm{~h}$ when the system pressure was about 1- $60 \mathrm{~Pa}$.

In this context, Shin and Eun. (2015) [32] used two precursors to synthesis TiC powders. For the first, TiC powder is synthesized from a micron-sized mesoporous metatitanic acid-sucrose precursor (precursor M) by a carbothermal reduction process. For the second, TiC powder is prepared using a nanosized $\mathrm{TiO}_{2}$-sucrose precursor (precursor T). The TiC prepared using precursor $\mathrm{M}$ at $1500^{\circ} \mathrm{C}$ for $2 \mathrm{~h}$ in argon exhibited similar properties to those of the powder obtained from precursor $\mathrm{T}$ in terms of the crystallite size ( 58.5 versus $57.4 \mathrm{~nm}$ ), oxygen content ( 0.22 versus $0.25 \mathrm{wt} \%$ ), and representative sizes of mesopores (2.5 versus 19.7-25 nm). Ren et al. (2015) [33] used carbothermal reduction method to synthesize TiC fine powders from titania and carbon black under vacuum. They obtanied a fine TiC powders with grain sizes of about $200 \mathrm{~nm}$.

Yu et al. (2007) [34] reported the synthesis of high surface area TiCcarbon composites with a SSA of $823 \mathrm{~m}^{2} \cdot \mathrm{g}^{-1}$ formed from the carbothermal reduction of titanium citrate with a triblock copolymer template at $1000{ }^{\circ} \mathrm{C}$ which resulted in 4 to $5 \mathrm{~nm}$ TiC nanocrystals suspended in a mesoporous carbon matrix with an over all stoichiometry of $\sim \mathrm{TiC}_{8}$. Additionally, Galevsky et al. (2015) [35] studied the effects of the major specifications of the fabrication technique on the content of titanium carbide and free carbon in the end product. They showed that carbidization of titanium is a preferable method of titanium carbide plasma fabrication. The experiments were carried out in the reactor heat-insulated by zirconium dioxide lining with wall thickness of $0.005 \mathrm{~m}$ and outside diameter of $0.066 \mathrm{~m}$ which reduces its diameter to $0.056 \mathrm{~m}$. Thus, titanium powder (alternative 1 ) and titanium dioxide (alternative 2) powder were chosen as raw materials, natural gas with methane content of $96 \%$ was used as carbide-forming agent.

Table 2 summarizes the methods and processing conditions on synthesis of titanium carbide by carbothermal reduction.

Table 2. Comparison of the methods and processing conditions on the synthesis of titanium carbide by carbothermal reduction

\begin{tabular}{|c|c|c|c|}
\hline Reactants & Process parameters & Product quality & Ref. \\
\hline $\begin{array}{l}\text { *Series A: } \\
\text { Ti(IV) chloride+ } \\
\text { ethyleneglycol+ acitric acid } \\
\text { (0.05M: 0.12M: } 0.8 \mathrm{M}) \\
\text { *Series B: } \\
\text { Ti(IV) n-propoxide + } \\
\text { saccharose + acetic acid (T:C } \\
=1: 3.7)\end{array}$ & $\begin{array}{l}\text { *Series A: } \\
\text { Heating rate 10- } \\
200^{\circ} \mathrm{C} / \mathrm{h} \text {; } 0.5 \mathrm{~h} ; \mathrm{Ar} \\
\text { *Series B: } \\
\text { Heating rate } 300- \\
350^{\circ} \mathrm{C} / \mathrm{h} ; 1-2 \mathrm{~h} ; \mathrm{Ar}\end{array}$ & $\begin{array}{l}\text { TiC nanopowder with } \\
\text { specific surface area of } \\
30-200 \mathrm{~m}^{2} / \mathrm{g} \text {. } \\
\text { Crystallites size of } 40- \\
45 \mathrm{~nm}\end{array}$ & [20] \\
\hline TiO, $\mathrm{C}_{\mathrm{gr}}$ and Ti metallic form & $\begin{array}{l}\mathrm{T}=293-2300 \mathrm{~K} ; \mathrm{t}= \\
1 \mathrm{~h} \text { and } \mathrm{t}=3 \mathrm{~h} ; \\
\text { Under vacuum } \\
\left(10^{-2} \leq \mathrm{P}(\mathrm{Pa}) \leq 10^{-1}\right)\end{array}$ & $\begin{array}{l}\text { TiC powders with } \\
\text { lattice parameter } \\
\text { between } 0.43800 \text { and } \\
0.43631 \mathrm{~nm}\end{array}$ & [21] \\
\hline $\begin{array}{l}8 \text { starting mixture: } 4 \\
\text { titanium dioxide grades ( } 3 \\
\text { rutiles grades }+ \text { anatase } \\
\text { grade) }+2 \text { carbon blacks ( } 1 \\
\text { acetylene }+1 \text { furnace black) }\end{array}$ & $\begin{aligned} \mathrm{T} & =1000-1500 \\
{ }^{\circ} \mathrm{C} ; \mathrm{t} & =30 \mathrm{~min} ; \mathrm{Ar}\end{aligned}$ & 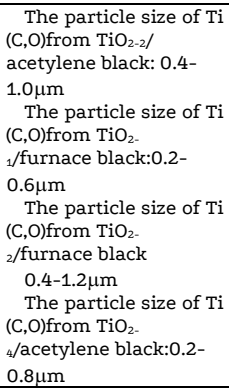 & [24] \\
\hline $\begin{array}{l}\text { Powder of } \mathrm{TiO}_{2}(68.9 \mathrm{wt} \%)+ \\
\text { powder of } \mathrm{C}(31.1 \mathrm{wt} \%)\end{array}$ & $\begin{array}{l}\mathrm{T}=1200^{\circ} \mathrm{C} ; 4 \mathrm{~h} ; \\
\text { under argon }(30 \mathrm{lh}- \\
\text { 1) }\end{array}$ & TiC of good purity & [25] \\
\hline $\begin{array}{l}\text { Titanium gel precursor }+ \\
\text { carbon particles }\end{array}$ & $\begin{aligned} & \mathrm{T}=1300-1580^{\circ} \mathrm{C} ; \mathrm{t} \\
= & 2 \mathrm{~h} ; \mathrm{Ar}\end{aligned}$ & Nano-TiC powder & {$[26]$} \\
\hline $\begin{array}{l}\text { Carbon+ coated titania } \\
\text { powder }\left(\mathrm{TiO}_{2}\right)\end{array}$ & $\begin{aligned} & \mathrm{T}=1200-1550^{\circ} \mathrm{C} ; \mathrm{t} \\
&= 4 \mathrm{~h} \text {; } \\
& \text { Inertatmosphere }\end{aligned}$ & $\begin{array}{l}\text { Fine particle size of } \\
\text { TiC }(0.1-0.3 \mu \mathrm{m}), \\
\text { oxygen content of } 0.57 \\
\text { wt } \% \text {; lattice parameter } \\
\text { of } 0.4331 \mathrm{~nm} \text {; uniform } \\
\text { particle shape } \\
\end{array}$ & [27] \\
\hline $\begin{array}{l}\text { Rutile }\left(\mathrm{TiO}_{2}\right) \\
\text { + Carbon black }\end{array}$ & ${ }_{\mathrm{Ar}}^{\mathrm{T}=1600^{\circ} \mathrm{C} ; \mathrm{t}=2 \mathrm{~h} ;}$ & $\begin{array}{l}\text { TiC with finer particle } \\
\text { size }(1 \mu \mathrm{m}) \text { and with } \\
\text { lower oxygen content } \\
(1.2-3.4 \mathrm{wt} \%)\end{array}$ & [28] \\
\hline $\begin{array}{l}\mathrm{TiO}_{2} \text { particles }(5 \mathrm{~nm} \text { in } \\
\text { diameter) + methyl cellulose } \\
(\mathrm{MC})\end{array}$ & $\begin{array}{l}\mathrm{T}=1200-1500^{\circ} \mathrm{C} ; \\
\text { heating rate of } \\
10^{\circ} \mathrm{C} / \mathrm{min} ; 2 \mathrm{~h} ; \mathrm{Ar}\end{array}$ & $\begin{array}{l}\text { TiC nanoparticle with } \\
\text { low oxygen content } \\
(0.60-2.32 \mathrm{wt} \%)\end{array}$ & [29] \\
\hline $\begin{array}{l}\mathrm{TiO}_{2} \text { powder consisting of } \\
\text { anatase and rutile phases } \\
\text { +carbon black }\end{array}$ & $\begin{array}{l}\mathrm{T}=1100-1550^{\circ} \mathrm{C} ; \\
\mathrm{t}=2-4 \mathrm{~h} ; \mathrm{Ar}\end{array}$ & $\begin{array}{l}\text { Submicron, high } \\
\text { purity, } \\
\text { TiC powders with } \\
\text { finer particle size } \\
(0.1 \mu \mathrm{m}) \text { and with lower } \\
\text { oxygen content (0.6 } \\
\text { wt } \%)\end{array}$ & [30] \\
\hline $\begin{array}{l}{ }^{*} \text { Micron-sized mesoporous } \\
\text { metatitanic acid-sucrose } \\
\text { precursor } \\
(\text { precursor } \mathrm{M}) ; \\
\text { ^ Nanosized } \mathrm{TiO}_{2} \text {-sucrose } \\
\text { precursor (precursor T) }\end{array}$ & $\begin{array}{l}\mathrm{T}=1500^{\circ} \mathrm{C} ; \mathrm{t}=2 \mathrm{~h} ; \\
\mathrm{Ar}\end{array}$ & $\begin{array}{l}\text { * Precursor M: } \\
\text { Crystallite size of } 58.5 \\
\mathrm{~nm} \text { and oxygen } \\
\text { content of } 0.22 \mathrm{wt} \% \\
\quad \text { * Precursor } \mathrm{T:} \\
\text { Crystallite size of } 57.4 \\
\mathrm{~nm} \text { and oxygen } \\
\text { content of } 0.25 \mathrm{wt} \% \\
\end{array}$ & [31] \\
\hline Titania + charcoal & $\begin{array}{l}\mathrm{T}=1450^{\circ} \mathrm{C} ; \mathrm{t}=8 \mathrm{~h} ; \\
\mathrm{P}=1-60 \mathrm{~Pa}\end{array}$ & $\begin{array}{l}\text { Fine TiC powders } \\
(\mathrm{D} 50,2.05 \mu \mathrm{m}) \text { with low } \\
\text { impurities }\end{array}$ & [32] \\
\hline $\begin{array}{l}\text { Titania }\left(\mathrm{TiO}_{2} \geq 99.5 \mathrm{wt} \%\right)+ \\
\text { carbon black }(\mathrm{C} \geq 99.5 \mathrm{wt} \%) \text {. } \\
\text { The average particle size of } \\
\mathrm{TiO}_{2} \text { and } \mathrm{C} \text { was } 20 \text { and } 30 \\
\mathrm{~nm} \text {, respectively. The molar } \\
\text { ratio of } \mathrm{C} \text { to } \mathrm{TiO}_{2} \text { was } 3: 1\end{array}$ & $\begin{array}{c}\mathrm{T}=1300^{\circ} \mathrm{C} ; \mathrm{t}=1 \mathrm{~h} ; \\
\mathrm{P}=20 \mathrm{~Pa} ; \text { in vacuum }\end{array}$ & $\begin{array}{l}\text { Fine TiC grains with } \\
\text { size of } 200 \mathrm{~nm}\end{array}$ & [33] \\
\hline $\begin{array}{l}\text { Titanium citrate + triblock } \\
\text { copolymer }\end{array}$ & $\begin{array}{l}\mathrm{T}=600-1000^{\circ} \mathrm{C} ; \\
\mathrm{t}=2-6 \mathrm{~h} ; \mathrm{Ar}\end{array}$ & $\begin{array}{l}\text { TiC with particle size } \\
\text { of } 4-5 \mathrm{~nm} \text { and with } \\
\text { high surface areas (up } \\
\text { to } 800 \mathrm{~m}^{2} \mathrm{~g}^{-1} \text { ) } \\
\text { TiC nanopowder } \\
\text { oxidation } \\
\end{array}$ & [34] \\
\hline $\begin{array}{l}\text { Alternative } \mathrm{I} \mathrm{TiO}_{2}+\text { natural } \\
\text { gas) Particle size, nm } \\
38-42\end{array}$ & $\begin{array}{l}\text { Tempering } \\
\text { temperature, } \mathrm{K} \\
2600-2800\end{array}$ & $\begin{array}{l}107, \mathrm{~kg} \mathrm{O} / \mathrm{m}^{2} \\
12.5\end{array}$ & [35] \\
\hline $\begin{array}{l}\text { Alternative II (Ti + natural } \\
\text { gas) Particle size, nm } \\
\text { 34-36 }\end{array}$ & $\begin{array}{c}\text { Tempering } \\
\text { temperature, } \mathrm{K} \\
2600-2800\end{array}$ & $\begin{array}{l}\text { TiC nanopowder } \\
\text { oxidation } \\
107, \mathrm{~kg} \mathrm{O}_{2} / \mathrm{m}^{2} \\
8.6\end{array}$ & [36] \\
\hline
\end{tabular}


Carbothermal reduction of $\mathrm{TiO}_{2}$ is an economical way for the production of $\mathrm{TiC}$, and probably the most important and economica method in industry for the commercial production of TiC. In the carbothermal reduction of $\mathrm{TiO}_{2}$, the raw materials $\mathrm{TiO}_{2}$ and carbon generally exist in the solid state as separate particles. So the contact area between the reactants was not wide enough which makes reaction very slow. This limits the extent of the synthesizing reaction. The effect of these limitations was a product that includes unacceptable quantities of un-reacted titanium dioxide and carbon [4]

\subsection{Chemical vapor deposition technique}

Chemical vapor deposition technique (CVD) is the deposition of a solid on the heated substrate from reactants in the vapor phase. The term CVD was introduced since 1960 to distinguish chemical vapor deposition process [36]. In 1968, start of industrial use of CVD coated cemented carbide [37]. The chemical reactions involved in the precursor to material conversion can include thermolysis, hydrolysis, oxidation, reduction, nitration, and carboration depending on the precursor species used [38]. Once the gaseous species are in proximity to the substrate or the surface itself, they can either adsorb directly on the catalyst particle or on the surface. Diffusion processes, as well as the concentration of the adsorbates, are responsible for the growth of a solid phase at the catalyst-surface interface.

Generally, the deposition of carbides was obtained by reacting a halide with a hydrocarbon using hydrogen or nitrogen gas. Noel and Kovar (2002) [39] synthesized TiC nanoparticles using CVD technique from the deposition of titanium and carbon powders on tantalum using hydrogen gas, titanium tetrachloride $\left(\mathrm{TiCl}_{4}\right)$ and either methane $\left(\mathrm{CH}_{4}\right)$ or acetylene $\left(\mathrm{C}_{2} \mathrm{H}_{2}\right)$ source gases. Amorphous fine titanium carbide powders have been prepared by CVD in the $\mathrm{TiCl}_{4}-\mathrm{CH}_{4}$ system at temperature ranging from 850 to $1050{ }^{\circ} \mathrm{C}$ in hydrogen atmosphere with pressure varying from less than $100 \mathrm{~Pa}$ to $1 \mathrm{~atm}$, as given in the following reaction [40]:

$\mathrm{TiCl}_{4(\mathrm{~g})}+\mathrm{CH}_{4(\mathrm{~g})}+\mathrm{H}_{2(\mathrm{~g})} \rightarrow \mathrm{TiC}_{(\mathrm{s})}+4 \mathrm{HCl}_{(\mathrm{g})}+\mathrm{H}_{2(\mathrm{~g})}$ (2)

The final product of this reaction is a hard and wear-resistant coating that exhibits a chemical bond to the substrate.

Stjernberg et al. (1977) [41] investigated the influence of various parameters on the CVD rate of $\mathrm{TiC}$ prepared from $\mathrm{TiC} 1_{4}-\mathrm{CH}_{4}-\mathrm{H}_{2}$ mixtures. They proposed a model based on the LangmuirHinshelwood adsorption reaction mechanism. They concluded that the deposition rate increases slightly with increasing pressure, the deposition rate was proportional to the $\mathrm{CH}_{4}$ content, the deposition rate was inversely proportional to the equilibrium $\mathrm{HCl}$ concentration in the reactor and the deposition rate was practically inversely proportional to the $\mathrm{TiCI}_{4}$ content of the inlet gas when no $\mathrm{HCl}$ was added. Additionally, TiC films were synthesized by photo-CVD using D2 lamp and gas mixture of $\mathrm{TiC}_{1}-\mathrm{CH}_{4}$ (or $\mathrm{CC}_{14}$ ) $-\mathrm{H}_{2}-\mathrm{Ar}$ [42]. It was concluded that the deposition rate of the TiC films was increased by 1.5-2.3 times by irradiation from a D2 lamp compared with that without irradiation, while the lowering of the deposition temperature with irradiation could not be attained.

$\mathrm{X}$-ray diffraction (XRD) and transmission electron microscopy (TEM) have been used to investigate the fine-scale microstructure of TiC obtained by chemical vapor deposition [43]. It was revealed that the microstructures have a considerable influence over both in grain plasticity and microcrack paths during deformation. Thus, considerable densities of structural defects are grown into all coatings and are expected to influence mechanical properties such as hardness. Considerable interfacial diffusional exchange of species between the coating and the substrate may occur and may influence coating adhesion.

Additionally, Tong and Reddy. (2005) [44] synthesized titanium carbide nanopowders by thermal plasma using $\mathrm{Ti}$ and $\mathrm{CH}_{4}$ as the starting materials. They reported that the average size of the obtained powders is less than $100 \mathrm{~nm}$ with non-stoichiometric composition. Kasimuthumaniyan et al. (2016) [45] prepared a fine titanium carbide powder by using titania-rich slag as a cheap raw material. The result revealed that the average particle size of $\mathrm{TiC}$ powder was $2.54 \mu \mathrm{m}$.

\subsection{Polymeric precursors based on either titanium alkoxides or} other organic compounds

Polymerizations of metal-organic compounds and sol-gel provide a new routes to produce carbides [46]. The development of new routes to non-oxide ceramics based on pyrolysis of oxygen-containing metal-organic polymeric precursors was the subject of several researches [47-50]. In this context, Jiang and Rhine (1991) [51] prepared titanium carbide, at $1150{ }^{\circ} \mathrm{C}$, by pyrolysis of a polymeric precursor formed by hydrolysis of a $\mathrm{Ti}\left(\mathrm{O}-\mathrm{n}-\mathrm{C}_{4} \mathrm{H}_{9}\right)_{4} /$ furfuryl alcohol mixture under argon. They reported that the temperature observed for the formation of $\mathrm{TiC}$ was lower than those reported for the formation of $\mathrm{TiC}$ by carbothermal reduction.

Stanley et al. (1992) [52] synthesized binary and ternary carbides by using the reaction of titanium tetra-isopropoxide with glycerol and furfuryl alcohol. The latter being used to control the oxide/carbon stoichiometry in the subsequent coke. They concluded that, by incorporating more than one metal in the precursor, it is possible to produce ceramic alloys at lower temperatures than conventional means allow. Lang and Seyferth (1990) [53] used precursors such as $\mathrm{TiC}_{\mathrm{p} 2}\left(\mathrm{CCC}_{6} \mathrm{H}_{5}\right)_{2}$ and $\mathrm{TiC}_{\mathrm{p} 2-\mu}-\mathrm{CH}_{2}$ to produce TiC. Gallo et al. (1990) [54] synthesized titanium carbide by pyrolysis of titanocene dichloride or titanocene dimethyl under argon atmosphere. Additionally, Ting et al. (1990) [55] reacted alkoxides with diacetates to form polymeric alkoxides and esters. They revealed, from XRD data, that the formed titanium carbide was sub-stoichiometric in carbon.

\subsection{Gas phase reactions of titanium tetrachloride $\left(\mathrm{TiCl}_{4}\right)$ and} hydrocarbons

The production of high pure product not achievable using conventional techniques because of problems such as crystallization, volatilization, or high melting temperatures. Gas phase reactions of $\mathrm{TiCl}_{4}$ and hydrocarbons are a new approach to synthesizing $\mathrm{TiC}$ [56]. The basic raw material for this method was $\mathrm{TiCl}_{4}$ and the process generally based on the gas-phase reaction between $\mathrm{TiCl}_{4}$ and an appropriate compound or hydrocarbon such as $\mathrm{C}_{2} \mathrm{H}_{2}, \mathrm{CCl}_{4}, \mathrm{CH}_{4}$, and $\mathrm{CaC}_{2}$

Grove et al. (2010) [57] fabricated titanium carbide nanoparticles by flowing methane through a plasma generated from an arc discharge between two titanium electrodes. Thus, different methane concentrations were employed to investigate the effects of carbon concentration on particle morphology. TiC cubes are synthesized at a low methane concentration and cuboctahedrons at a high methane concentration. However, Harbuck et al. (1986) [58] synthesized titanium carbide using sodium reduction of $\mathrm{TiCl}_{4}$ at $800{ }^{\circ} \mathrm{C}$ in a methane atmosphere. They concluded that only $20 \%$ of the $\mathrm{TiCl}_{4}$ was converted to powder, and XRD analysis showed that it composed of TiO with a small amount of un-dissolved $\mathrm{NaCl}$ and no appreciable amount of titanium carbide. Hence, uniformly fine size powders, suitable for industrial applications, are produced.

\subsection{Self-propagating high-temperature synthesis}

Self-propagating high-temperature synthesis (SHS) technology, which was originally discovered by Goldschmidt (1895) [59] and later was systematically developed by Merzhanov (1990) [60], has been proved to be an efficient and energy-saving method for obtaining many high melting point materials. SHS processes present great possibilities to control the sizes and morphology of synthesized ceramic particles [61]. Thus, SHS was a promising method to produce structural materials because it features simplicity of the process and equipment, efficiency in energy and time, and high purity of products [62]. However, SHS of powder compacts was also known as combustion synthesis and proceeds via exothermic reactions. Since the process occurs at high temperatures, this method can be used as an alternative to conventional furnace technology [63].

Nersisyan (2002) [64] used SHS method to synthesize nanosized TiC powder. They added sodium chloride $(\mathrm{NaCl})$ as inert and inorganic compounds to prevent particle agglomeration in the combustion synthesis. They found that the mechanism of TiC formation contains four steps (as shown in Fig. 4). In the first stage, $\mathrm{NaCl}$ was added to the initial mixture reactants ( $\mathrm{Ti}$ and $\mathrm{C}$ ). The second stage: melting of $\mathrm{NaCl}$ occurs. During the third stage: melting of Ti. Finally, during the last 
stage: rystallization of $\mathrm{TiC}$ and subsequent protection by $\mathrm{NaCl}$ (formation of submicron and nanosized TiC particles).

Nanostructured TiC powders have been prepared by self-propagating high-temperature synthesis [65]. It was shown that the TiC grain size depends on temperature, in the range of $T_{\max }-1000 \mathrm{~K}$, and on time elapsed in this temperature range.

Zhang et al. (2012) [66] prepared TiC terraces by self-propagating hightemperature synthesis reaction with 10 wt. \% Fe-Ti-C elemental powder mixtures. They found that the dissolution reaction precipitation mechanism was responsible for the formation of TiC.

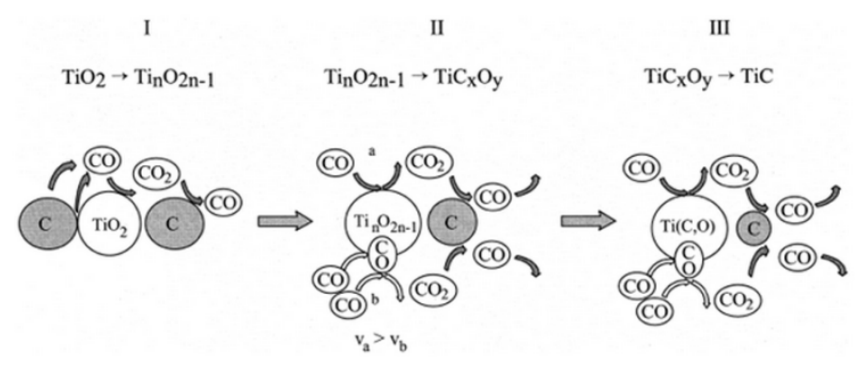

Figure 4. Mechanism of TiC structure formation according to SHS reaction stages: (a) initial step, (b) melting of $\mathrm{NaCl}$, (c) melting of $\mathrm{Ti}$, and (d) crystallization of $\mathrm{TiC}$ and subsequent protection by $\mathrm{NaCl}$ [64]

Similarly, Ali-Rachedi et al. (2010) [67] concluded that the heat loss during the SHS reaction significantly influences combustion temperature, propagation rate, stability, and the geometry of a reactant sample becomes an important factor because of the effect of dimension on heat loss. However, it was concluded that the combustion rate increased as the diameter of a cylindrical sample increased and remained constant after the diameter reached a certain value, which was dependent on the reaction system $[68,69]$.

\section{6. $\mathrm{Mg}$-thermal reduction}

The techniques already mentioned have weak points such as easy oxidation, formation of the non-stoichiometric composition; require initial powder of high purity, and coarse particle formation. However, nanostructured titanium carbides were synthesized by liquidmagnesium reduction of vaporized $\mathrm{TiCl}_{4}+\mathrm{CCl}_{4}$ solution [70,71]. Fine $\mathrm{TiC}$ particles were obtained from $\mathrm{Ti}$ and $\mathrm{C}$, and vacuum was used to remove the residual phases of $\mathrm{MgCl}_{2}$ and excess $\mathrm{Mg}$. The crystallite size was about $50 \mathrm{~nm}$ and the lattice parameter of the TiC was 0.43267 $\mathrm{nm}$. Lee et al. (2009) [72] fabricated ultrafine titanium carbonitride particles $\left(\mathrm{TiC}_{0.7} \mathrm{~N}_{0.3}\right.$ ) by the nitridation treatment at $1473 \mathrm{~K}$ of $\mathrm{TiC}_{0.7}$ nanoparticles, which were produced by the magnesium reduction of the gaseous $\mathrm{TiCl}_{4}+\mathrm{xC}_{2} \mathrm{Cl}_{4}$ at temperature of $1163 \mathrm{~K}$. Thus, the stoichiometry form of the product was $\mathrm{TiC}-0.67 \mathrm{~N}-0.27$ could be successfully produced by post nitrification heat treatment at $1373 \mathrm{~K}$ and their purity higher was than $99.5 \%$ showing a mean particle size of about $100 \mathrm{~nm}$.

Additionally, Lee et al. (2013) [73] synthesized nanosized TiC and TiCN powders by magensiothermic reduction from $\mathrm{TiCl}_{4}+\mathrm{C}_{2} \mathrm{Cl}_{4}$ solution. They revealed that the mean particle size was about $100 \mathrm{~nm}$, and the surface morphology of the final product was closer to round shape. Lee et al. (2005) [74] produced nanophase titanium carbonitrides by Mg-thermal reduction of the $\mathrm{TiCl}_{4}+\mathrm{C}_{2} \mathrm{Cl}_{4}$ solution in the isolated chamber with nitrogen atmosphere. High quality of crystal form of $\mathrm{TiC}_{0.46-0.53} \mathrm{~N}_{0.46-0.51}$ and about $0.1 \mathrm{wt} \%$ free carbon were produced. The reaction temperatures and the solution feeding rates significantly influenced the stoichiometry not of $\mathrm{C}$ but of the $\mathrm{N}$ side. The products showed porous sponge shape agglomeration with fine particles with size of about $50 \mathrm{~nm}$.

Lee et al. (2007) [75] fabricated TiC and TiCNnanoparitcles by magnesium thermal reduction process. This process was performed in four steps: the transfer of $\mathrm{TiCl}_{4}+\mathrm{C}_{2} \mathrm{Cl}_{4}$ solutions into a liquefied magnesium protected with $\mathrm{Ar}$, the magnesium reduction of metal chlorides, the formation of a titanium carbide by the reaction of $\mathrm{Ti}$ and $\mathrm{C}$ atoms released by the magnesium reduction, and finally the vacuum separation of the residual liquid $\mathrm{Mg}$ and $\mathrm{MgCl}_{2}$. The average particle size of both $\mathrm{TiC}$ and $\mathrm{TiCN}$ was about $80 \mathrm{~nm}$ each. Lee et al. (2005) [76] produced nanosized titanium carbide particles by the reaction of liquid magnesium and vaporized $\mathrm{TiCl}_{4}+\mathrm{xC}_{2} \mathrm{Cl}_{4}$ solution. They concluded that the use of the $\mathrm{TiCl}_{4}+\mathrm{C}_{2} \mathrm{Cl}_{4}$ solution was more advantageous for increasing the stoichiometry of titanium carbide than $\mathrm{TiCl}_{4}+\mathrm{C}_{2} \mathrm{Cl}_{4}$. The crystallite size of the final product was about 50 $\mathrm{nm}$ and the lattice parameter was $0.43267 \mathrm{~nm}$. The following Table 3 summarizes the obtained results of the as synthesized materials:

Table 3. Properties of TiC prepared by $\mathrm{Mg}$-thermal reduction

\begin{tabular}{|c|c|c|c|}
\hline $\begin{array}{l}\text { Starting } \\
\text { materials }\end{array}$ & Final product & $\begin{array}{c}\text { Groove } \\
\text { dimensions (size, } \\
\text { lattice parameter) }\end{array}$ & Reference \\
\hline $\mathrm{TiCl}_{4}+\mathrm{CCl}_{4}$ & TiC particles & $\begin{array}{l}\mathrm{d} \sim 50 \mathrm{~nm} \\
\mathrm{a}=0.43267 \mathrm{~nm}\end{array}$ & {$[70,71]$} \\
\hline $\begin{array}{l}\mathrm{TiCl}_{4}+ \\
\mathrm{C}_{2} \mathrm{Cl}_{4}\end{array}$ & $\begin{array}{l}\mathrm{TiC}_{0.7} \mathrm{~N}_{0.3} \\
\text { particles }\end{array}$ & $\begin{array}{l}\text { High purity } \\
(99.5 \%) \\
d \sim 100 \mathrm{~nm}\end{array}$ & [72] \\
\hline $\begin{array}{l}\mathrm{TiCl}_{4}+ \\
\mathrm{C}_{2} \mathrm{Cl}_{4}\end{array}$ & $\begin{array}{l}\text { TiC and TiCN } \\
\text { nanosized } \\
\text { powders }\end{array}$ & $\begin{array}{l}\text { Round shape } \\
\mathrm{d} \sim 100 \mathrm{~nm}\end{array}$ & [73] \\
\hline $\begin{array}{l}\mathrm{TiCl}_{4}+ \\
\mathrm{C}_{2} \mathrm{Cl}_{4}\end{array}$ & $\mathrm{TiC}_{0.46-0.53} \mathrm{~N}_{0.46-0.51}$ & $\begin{array}{l}\text { Porous sponge } \\
\text { shape } \\
\mathrm{d} \sim 50 \mathrm{~nm}\end{array}$ & [74] \\
\hline $\begin{array}{l}\mathrm{TiCl}_{4}+ \\
\mathrm{C}_{2} \mathrm{Cl}_{4}\end{array}$ & $\begin{array}{l}\mathrm{TiC} \text { and } \mathrm{TiCN} \\
\text { nanoparicles }\end{array}$ & $\mathrm{d} \sim 80 \mathrm{~nm}$ & [75] \\
\hline $\begin{array}{l}\mathrm{TiCl}_{4}+ \\
\mathrm{C}_{2} \mathrm{Cl}_{4}\end{array}$ & $\begin{array}{l}\text { TiC nanosized } \\
\text { particles }\end{array}$ & $\begin{array}{l}d=50 \mathrm{~nm} \\
\mathrm{a}=0.43267 \mathrm{~nm}\end{array}$ & [76] \\
\hline
\end{tabular}

\subsection{Sol-gel process}

Sol-gel technology has already long history, starting with processing of oxide materials including glass and ceramics about 30 years ago. Since then, the technology was employed in preparation not only of oxides, but also of non-oxide materials including nitrides, carbides, fluorides, and sulfides as well as oxynitride and oxycarbide glasses. Processing of organic-inorganic materials is now a very active field of research, which has been expanded even in the field of biotechnology as is represented by research on encapsulation of enzymes, antibodies and bacteria. Sol-gel process is a known chemical route to prepare powders, microtubes, fibres, and films [77, 78]. Moreover, the use of molecular precursors and the control of the synthesis conditions make it possible to prepare homogeneous and pure multicomponent systems [79].

Press et al. (1995) [80] used sol-gel method to obtain precursors which included metal alkoxide and polymeric carbon for the formation of TiC nanoparticles with high homogeneity at a molecular scale. Generally, the materials produce by sol-gel technique are highly porous in nature due to the evolution of gases during carbonization and carbothermal reduction of gel precursors and thus exhibit lower densities compare with the theoretical value of $3.21 \mathrm{~g} / \mathrm{cm}^{3}$ [81].

\subsection{Mechanical alloying}

Since 1970, the term mechanical alloying (MA) has been used to refer to the production of homogeneous composite particles with intimately dispersed uniform internal structure [82]. This technique also was easily-design component, reliable, more safety, and without considering the melting point of starting elements.

The main experimental parameters that must be taken into account to control the final products of a milling process are:

- Type of mill,

- Milling container

- Milling speed,

- Milling time,

- Type, size, and size distribution of the milling medium,

- Ball-to-powder weight ratio,

- Extent of filling the vial.

- Milling atmosphere, 
- Process control agent,

- Number and diameter of balls,

- Temperature of milling.

Since 1996, the first work reported by El-Eskandarany (1996) [83] reported the possibility of preparing titanium carbide nanopowders by MA from elemental Ti and $C$ powders at room temperature under argon atmosphere. Based on the XRD analysis it was concluded that the fcc- $\mathrm{Ti}_{44} \mathrm{C}_{56}$ powders was obtained after a very short milling time (20 ks).

Razavi et al. (2008) [84] concluded that the temperature for the synthesis of TiC can be reduced by increasing the milling time of precursors. Furthermore, milling led to increase of strain and decrease of TiC lattice parameter. Razavi et al. (2007) [85] fabricated nanosized TiC powders from impure Ti chips by MA in planetary ballmill. They found that the crystallite size of the produced TiC is less than $10 \mathrm{~nm}$, after $15 \mathrm{~h}$ of milling, and raising the milling time caused the increase of the strain and the fineness of the particles. Nanocrystalline TiC, with average crystallite size of $4 \mathrm{~nm}$, was synthesized by MA for $15 \mathrm{~h}$ from Ti powders and different carbon resources like carbon fibers, carbon nanotubes, and activated carbon [86].

Fig. 5 illustrates the mechanism of formation of nanocrystalline TiC by MA of $\mathrm{Ti}$ and activated carbon powders. During the initial stage of milling, the carbon powders are crushed into smaller particles and the titanium particles are deformed and fragmented caused by plastic deformation induced during MA. In this stage, no TiC can be formed. During the second stage of milling, with increasing milling time, the titanium and carbon powders are refined: the fine particles of carbon are entrapped between the big particles of titanium. In addition, no TiC can be formed. During the third stage of milling, a little amount of $\mathrm{TiC}$ was formed on the surface of the Ti particles caused by defects. Finally, the as-milled products are completely composed of nanocrystalline $\mathrm{TiC}$ powder.

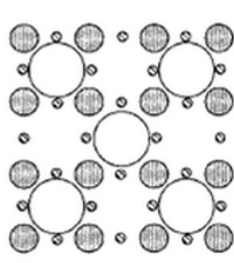

(a)

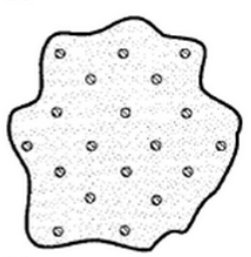

(c)

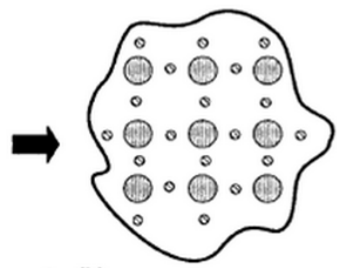

(b)

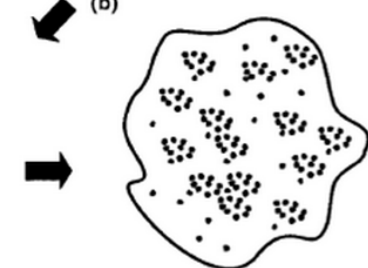

(d)

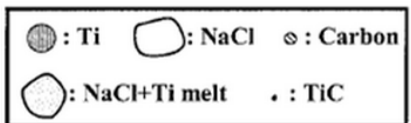

Figure 5. A schematic showing the reaction progress of $\mathrm{Ti}$ and activated carbon powders during MA. (a) Initial stage, no TiC; (b) second stage, the refinement of the $\mathrm{Ti}$ and carbon powders, no TiC; (c) third stage, a little amount of TiC formed on the surface of the Ti particles; (d) final stage, the milled products completely composed of nanocrystalline TiC [86]

Moreover, Cui et al. (2002) [87] used reactive milling to synthesize titanium carbide powder from the milled blends of titania/titanium/petroleum coke. They also studied the effect of percentage composition of element $\mathrm{Ti}$ on the synthesis of TiC. They concluded that the amount of element $\mathrm{Ti}$ added played an important role in the transformation from $\mathrm{TiO}_{2}$ to TiC. Zhu et al. (2001) [88] reported that MA was a power process to obtain nanocrystalline TiC powder with particle size of $5.64 \mu \mathrm{m}$ and crystalline size of $10 \mathrm{~nm}$. Lohse et al. (2007) [89] found that when milling $\mathrm{Ti}_{50} \mathrm{C}_{50}$ and $\mathrm{Ti}_{60} \mathrm{C}_{40}$ powder mixtures in impact mode using a magneto ball mill, TiC was formed via a mechanically induced selfpropagating reaction, indicated by an abrupt increase in the temperature of the milling vial that corresponded to the formation of $\mathrm{TiC}$. Thus, when milling $\mathrm{Ti}_{70} \mathrm{C}_{30}$ in impact mode using the same ball mill, the reaction to form $\mathrm{TiC}$ proceeded gradually as milling progressed.

In this context, TiC nanocomposite powder was synthesized from rutile and carbon black by mechanically activated sintering [90]. The mixture was MA in a planetary ball mill for $50 \mathrm{~h}$ under argon atmosphere to avoid oxidation. For complete reaction of the activated milled powder, heat treatment was carried out in an atmosphere controlled tube furnace. Tang et al. (2006) [91] prepared nanocrystalline $\mathrm{Ti}_{50} \mathrm{C}_{50}$ powder via MA from elemental titanium and graphite powder for $80 \mathrm{~h}$ of milling. Similarly, Ali and Basu (2010) [92] synthesized nanostructured TiC powder from industrial ferrotitanium MA for $40 \mathrm{~h}$ and subsequently heat treated at $1000{ }^{\circ} \mathrm{C}$ for $15 \mathrm{~min}$.

Ghosh and Pradhan (2010) [93] obtained nanocrystalline TiC powder after 35 min of milling in a high energy planetary ball mill. ElEskandarany et al. (1996) [94] prepared nanocrystalline $\mathrm{Ti}_{44} \mathrm{C}_{56}$ powder by MA of elemental titanium and graphite powders in a planetary mil after $200 \mathrm{~h}$ of milling. Viljus et al. (2001) [95] produced TiC by milling of $\mathrm{Ti}$ and $\mathrm{C}$ powders for $8 \mathrm{~h}$ with attritor ball mill at room temperature. Fine grained TiC powder was obtained. Similarly, Zhu et al. (2001) [96] synthesized nanocrystalline $\mathrm{TiC}$ powder from elemental $\mathrm{Ti}$ and $\mathrm{C}$ powders by using $\mathrm{GN}-2$ ball mill during $10 \mathrm{~h}$ of milling. Thus, nanocrystalline TiC, with crystallite size of $\sim 20 \mathrm{~nm}$, was obtained for $120 \mathrm{~min}$ of milling. However, after the subsequent milling, the crystalline size decreased gradually to reach $\sim 7 \mathrm{~nm}$ for $10 \mathrm{~h}$ of milling.

\subsection{Liquid phase sintering technique}

Liquid phase sintering (LPS) is today a well known and established manufacturing route in powder metallurgy [97]. This approach permits the formation of dense, pore-free carbides with properties superior to any previously know cutting materials. In LPS a powder mixture consisting of the alloy powder and sometimes a binder/lubricant is pressed into a green body. This green body was then heated to a temperature where a liquid phase was formed. The consolidation of the green body into a dense body consists of three stages: (i) particle rearrangement due to surface forces within the compact, (ii) solution reprecipitation type of rearrangement of the particles, and (iii) finial pore closure and grain growth. It can be shown that the driving force for the densification, as well as being a function of the surface energy of the liquid phase, was directly affected by the contact angle liquid-solid [98-100]. However, one of the most important key parameters for LPS process is to control excessive grain growth due to grain boundary motion and Ostwald ripening of carbide phase during LPS [101].

Very often hot pressing has also been used at 2073-2473 K temperatures. In this context, Meredith and Milner (1976) [102] studied the densification of TiC-Co system by varying Co contents $(0$, $5,10,20,30,40,50$, and 60 vol.\%) sintered in 0.2 torr of argon at 1400 ${ }^{\circ} \mathrm{C}$, i.e. $40{ }^{\circ} \mathrm{C}$ above the eutectic temperature. After $2 \mathrm{~min}$, at temperature of $1400{ }^{\circ} \mathrm{C}$, the density of the nominally $0 \%$ Co alloy increased by about $15 \%$ and thereafter, with extended sintering times, there was a small but steady increase. They concluded that TiCCo system show some anisotropy of particle shape, characterized by steady densification accompanied by the growth of neck contacts between particles, rounding of particles, and particle growth. Molybdenum was added to TiC-base alloys to prevent grain growth and improve the toughness. Thus, the effect of Mo was studied by adding it to the $1 / 2-2 \mu \mathrm{m}$ TiC-Co system. It was shown that molybdenum reduces the rates of enhanced surface and interfacial diffusion and therefore reduces the rate of material transport, so that there is less densification and particle growth. It also studied the densification of $\mathrm{TiC}-\mathrm{Ni}$ by LPS process. It was found that $\mathrm{TiC}-\mathrm{Ni}$ exhibits mixed isotropic and anisotropic characteristics: densification takes place by the growth of neck contacts between particles but the particles take up individual prismatic forms which act against collective close-packing and densification. Viljus et al. (2012) [103] synthesized Ti-C-Ni-Mo composite from elemental powders of $\mathrm{Ti}, \mathrm{Ni}$, Mo, and $C$ by using a high energy ball-milling followed by reactive sintering. The carbide was produced during low temperature heating $\left(1000^{\circ} \mathrm{C}\right)$, which eliminates expensive long-time, high-temperature 
$\left(1800-2000{ }^{\circ} \mathrm{C}\right)$ synthesis of TiC powder. The surface of as formed nanosize carbide particles was free from oxide film, absorbed gas or other detrimental surface contamination. It was shown that thermodynamically stable carbide grains, within the metal matrix, are formed.

For the case of two mixed powders, the mechanism of the microstructure changes during LPS process is shown in Fig. 6 [104] During heating, the solid grains undergo solid-state sintering. In fact, different microstructure evolutions are possible, depending on the solid liquid solubility relations. The common situation was for the liquid to wet the solid. In this case, the formed liquid penetrates between the grains, dissolves the sinter bonds, and causes grain rearrangement. Further, the liquid improves transport rates responsible for densification and coarsening, because of solid solubility in the liquid. The surface energy associated with pores leads to their annihilation, while there is progressive microstructure coarsening and bonding to increase rigidity.

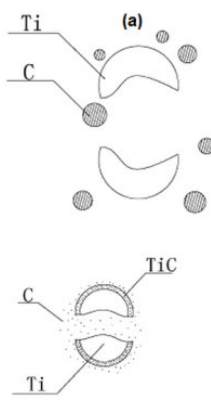

(c)
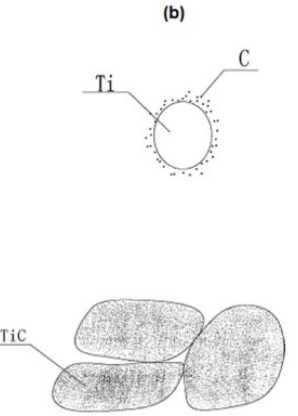

(d)
Figure 6. Mechanism of the microstructure changes during LPS process [104]

\subsection{Spark plasma sintering technique}

A novel sintering process recently developed in Japan, known as spark plasma sintering (SPS) [105] consisting of generating internally heat by means of DC current pulses directly through a graphite die containing the powder compact. In fact, the SPS technique has several advantages that distinguish it from the traditional sintering methods such as hot pressing and sintering of pre-compacted billets without pressure [106]. SPS enables liable control of the material microstructure and sintering process parameters.

In the last few years, increasing attention has been paid to fabricate carbides by SPS technique. El-Eskandarany and Al-Haza (2014) [107] used this technique to synthesize fully dense nanocrystalline $\mathrm{Ti}_{55} \mathrm{C}_{45}$ bulk material. Thus, the powders MA for $200 \mathrm{~h}$ were binderless consolidated in vacuum at $1500{ }^{\circ} \mathrm{C}$ under a pressure of $34.5 \mathrm{MPa}$, with heating rates of $20{ }^{\circ} \mathrm{C} / \mathrm{min}$ and $500{ }^{\circ} \mathrm{C} / \mathrm{min}$, respectively. They found that the sintered powders maintained their nano-scale. Hence, the vickers hardness, young's modulus, shear modulus and fracture toughness of the bulks were $32 \mathrm{GPa}, 358 \mathrm{GPa}, 151 \mathrm{GPa}$, and $6.4 \mathrm{MPa} \cdot \mathrm{m}^{1 / 2}$ respectively.

Cabrero et al. (2011) [108] used SPS, at $1800^{\circ} \mathrm{C}$ and under $75 \mathrm{MPa}$, to consolidate nanosized TiC powder (with particle size of $80 \mathrm{~nm}$ ) and achieved a density of $\sim 95.4 \%$. It's interesting to remark that even with decreasing the particles size from micro to nano range, higher density can't be reached.

Cheng et al. (2012) [109] consolidated micro-sized TiC powder ( $2 \mu \mathrm{m}$ in size), at $1500{ }^{\circ} \mathrm{C}$ and at pressure of $50 \mathrm{MPa}$, using SPS. The achieved density of the compact reaches about $95.7 \%$. Additionally, Li et al. (2015) [110] fabricated TiC-ZrC composite by SPS of TiC with $20 \mathrm{~mol} \%$ of $\mathrm{ZrC}$ particles at $1900{ }^{\circ} \mathrm{C}$ and at a pressure of $100 \mathrm{MPa}$ and achieved $99 \%$ density. Similary, Wang et al. (2004) [111] reinforced $30 \mathrm{wt} . \%$ of $\mathrm{SiC}$ nanoparticles in $\mathrm{TiC}$ and produced $\mathrm{TiC}-\mathrm{SiC}$ composite by SPS at $1600{ }^{\circ} \mathrm{C}$ under a pressure of $70 \mathrm{MPa}$ and achieved about $99 \%$ density.

\section{Applications of titanium carbide}

Titanium carbide attracted great interest for several structural applications. Therefore, TiC can be used in cutting tools because of its combination of wear resistance and high hardness. It can also be used as a coating for abrasive steel bearings and wear resistant tools. In addition, it can be used to enhance the conductivity of materials and as a nucleating agent.

In the middle of the 1960s, the wear resistance of such tools was increased appreciably by the deposition of thin coatings of TiN, TiC, and other refractory compounds [112]. The increase in the lifetime of the tools due to such coatings depends on the improved wear resistance and the lower cutting temperature due to a reduced friction between the tool and the work material. During the last years, the domains of application for these coatings have been extended to ordinary steel tools and high-speed steels. Commercially, high-speed steel drills coated with TiN have been introduced [113]. The wear life of such coated drills is 4 to 6 times longer than that of uncoated drills. In addition, coated drills show better resistance to corrosion and erosion [114]. TiC are also used in electronic devices, as diffusion barriers in integrated circuits [115], molded bipolar plates for highvoltage battery, and fuel power sources [116].

Moreover, TiC is employed as coatings for pump shafts, packing sleeves, feed screws for the chemical industry, as coatings for molding tools, and kneading elements for plastic processing. They are also utilized as coatings for fusion-reactor applications. TiC is very suitable for use high-speed cutting tool applications for reducing thermal stresses and cracking [117].

Furthermore, TiC is effectively utilised in cermets due to its low friction coefficient and higher oxidation resistance compared to cemented tungsten carbide [118]. TiC is also widely used in different branches of machine construction due to its high strength and hardness [119].

\section{Conclusions}

We review the synthesis and application of titanium carbide material; in particular, the properties and mechanisms are summarized. Particular attention has been paid to the study of all parameters involved in TiC production. At the present time, we note that solid chemical precursors can be used to synthesize material with desired properties. The applications of this material in ceramic science, engineering, and electronic are also reviewed. We also believe that this work will benefit physicists, engineering, and chemists with interest in titanium carbide and their applications.

Based on the above literature, it is good to think about those different ways of manufacturing TiC powder,ecause there is a high demand for composite materials with superior intrinsic properties for various industrial applications.

At present, most of the works on titanium carbide material are still at the laboratory level, with few reaching the practical application level. Therefore, it is necessary to predict the following suggestions: - It is necessary to ensure the homogeneity andintegrity of TiC material.

- The significant challenge is that the fabrication of high performance structural material with superfine microstructures.

- TiC is widely used in structural applications. It is necessary to develop functional applications.

\section{Nomenclature}

$\begin{array}{ll}\text { TiC } & \text { : Titanium carbide } \\ \text { CVD } & \text { : Chemical vapor deposition } \\ \text { LISHS } & \text { : Self-propagating high-temperature synthesis } \\ \text { TiCl }_{4} & \text { : Titanium tetrachloride } \\ \text { MA } & \text { : Mechanical alloying } \\ \text { LPS } & \text { : Liquid phase sintering } \\ \text { SPS } & \text { : Spark plasma sintering technique }\end{array}$

\section{Declaration of Conflict of Interests}

The authors declare that there is no conflict of interest. 


\section{Acknowledgments}

The authors are grateful to Dr. Faiçal Khlissa for helpful comments on a draft of this manuscript.

\section{References}

[1.] Zhou, Y., Sun, Z.. Crystallographic relations between $\mathrm{Ti}_{3} \mathrm{SiC}_{2}$ and TiC. Material Research Innovation 3 (2000) 286-291.

[2.] Li, S.B., Xiang, W.H., Zhai, H.X., Zhou, Y.. Formation of TiC hexagonal platelets and their growth mechanism. Powder Technology 185 (2008) 549-553.

[3.] Liu, Z.G., Tsuchiya, K., Umemoto, M.. Mechanical milling of fullerene with carbide forming elements. Journal of Materials Science 37 (2002) 1229-1235.

[4.] Mohapatra, S., Chaubey, A.K., Mishra, D.K., Singh, S.K.. Fabrication of Al-TiC composites by hot consolidation technique: its microstructure and mechanical properties. Journal of Materials Research and Technology 175 (2015) 6.

[5.] Hung, N.P., Boey, F.Y.C., Khor, K.A., Oh, C.A. Lee, H.F. Machinability of cast and powder formed aluminium alloys reinforced with SiC particles. Journal of Material Processing Technology 48 (1995) 291-297.

[6.] Akshay, D., Pradeep, K., Inderdeep, S.. Experimental investigation and optimization in EDM of Al $6063 \mathrm{SiC}$ metal matrix composite. International Journal of Machining Machinability of Materials 5 (2008) 293-308.

[7.] Agarwal, A., Singh, H., Kumar, P., Singh M..Optimisation of power consumption for CNC turned parts using response surface methodology and Taguchi's technique-A comparative study. Journal of Material Processing Technology 200 (2008) 373-384.

[8.] Yan, B.H., Wang, C.C., Chow, H.M., Lin, Y.C.. Feasibility study of rotary electro-discharge machining with ball burnishing for $\mathrm{Al}_{2} \mathrm{O}_{3} / 6061 \mathrm{Al}$ composite. International Journal of Machine Tools and Manufacture 40 (2000) 1403-1421.

[9.] Chiang, K.T.. Modeling and analysis of the effects of machining parameters on the performance characteristics in EDM process of $\mathrm{Al}_{2} \mathrm{O}_{3}+\mathrm{TiC}$ mixed ceramic, International Journal of Advanced Manufacturing Technology 37 (2008) 523-533.

[10.] Chiang, K.T., Chang, F.P.. Applying grey forecasting method for fitting and predicting the performance characteristics of an electro-conductive ceramic $\left(\mathrm{Al}_{2} \mathrm{O}_{3}+30 \%\right.$ TiC) during electric discharge machining. International Journal of Advanced Manufacturing Technology 33 (5-6) (2007) 480-488.

[11.] Okamoto, H.. C-Ti (Carbon-Titanium). Journal of Phase Equilibria 19 (1998) 89.

[12.] Hassine, N.A., Binner, J.G.P., Cross, T.E.. Synthesis of refractory metal carbide powders via microwave carbothermal reduction. International Journal of Refractory Metals and Hard Materials 13 (1995) 353-358.

[13.] Lin, H., Tao, B., Xiong, J., Li, Q.. Using a cobalt activator to synthesize titanium carbide (TiC) nanopowders. International Journal of Refractory Metals \& Hard Materials 41 (2013) 363-365.

[14.] Wang, J., Gao, D.N.Y., Lu, C., Fang, Z., Xu, Z.. A new method of fabrication of TiC by employing pyrolytic carbon black and titanium. International Journal of Refractory Metals \& Hard Materials 45 (2014) 137-140.

[15.] Muller, F., Monaghan, J.. Non-conventional machining of particle reinforced metal matrix composites. International Journal of Machine Tools and Manufacture 40 (2000) 1351-1366.
[16.] Muller, F., Monaghan, J.. Non-conventional machining of particle reinforced metal matrix composites. Journal of Material Processing Technology 118 (2001) 278-285.

[17.] Woo, Y.C., Kang, H.J., Kim, D.J.. Formation of TiC particle during carbothermal reduction of TiO. Journal of the European Ceramic Society 27 (2007) 719-722.

[18.] George PM, Ragunath BK, Manocha LM, Ashish M Warrier, Modeling of machinability parameters of carbon-carbon composite-a response surface approach, Journal of Material Processing Technology, (2004) 153-154: 920-924.

[19.] Berger, L.M., Gruner, W., Langholf, E., Stolle, S.. On the mechanism of carbothermal reduction processes of $\mathrm{TiO}_{2}$ and $\mathrm{ZrO}_{2}$. International Journal of Refractory Metals and Hard Materials 17 (1999) 235-243.

[20.] Zālīte, I., Letlena, A.. Synthesis and characterization of nanosized titanium carbide by carbothermal reduction of precursor gels. Materials Science-Medžiagotyra 18 (2012) 75-78.

[21.] Afir, A., Achour, M., Saoula, N..X-ray diffraction study of Ti-O-C system at high temperature and in a continuous vacuum. Journal of Alloys and Compounds 288 (1999) 124-140.

[22.] Wei, S., Xu, B.Q., Yang, B., Sun, H.Y., Song, J.X., Wan, H.L., Dai, Y.N. Preparation of TiC powders by carbothermal reduction method in vacuum. Transactions of Nonferrous Metals Society of China, 21 (2011) 185-190

[23.] Sarkar, D., Chu, M., Cho, S.J.. Synthesis and morphological analysis of titanium carbide nanopowder. Journal Am Ceram Soc 92 (2009) 2877-2882

[24.] Berger, L.M.. Titanium carbide synthesis from titanium dioxide and carbon black. International Journal of Refractory Metals and Hard Materials 3 (1992) 3-15.

[25.] Maitre, A., Tetard, D., Lefort, P..Role of some technological parameters during carburizing titanium dioxide. Journal of the European Ceramic Society 2 (2000) 15-22.

[26.] Chandra, N., Sharma, M., Singh, D.K., AmritphaleS.S.. Synthesis of nano-TiC powder using titanium gel precursor and carbon particles. Materials Letters 63 (2009) 1051-1053.

[27.] Koc, R.. Kinetics and phase evolution during carbothermal synthesis of titanium carbide from carbon-coated titania powder. Journal of the European Ceramic Society 17 (1997) 13091315.

[28.] Preiss, H., Berger, L.M., Schultze, D.. Studies on the carbothermal preparation of titanium carbide from different gel precursors. Journal of the European Ceramic Society 19 (1999) 195-206.

[29.] Gotoh, Y., Fujimura, K., Koike, M., Ohkoshi, Y., Nagura, M., Akamatsu, K., Deki, S.. Synthesis of titanium carbide from a composite of $\mathrm{TiO}_{2}$ nanoparticles/methyl cellulose by carbothermal reduction. Materials Research Bulletin 36 (2001) 2263-2275

[30.] Koc, R., Folmer, J.S.. Carbothermal synthesis of titanium carbide using ultrafine titania powders. Journal of Materials Science 32 (1997) 3101-3111.

[31.] Sen, W., Sun, H., Yang, B., Xu, B., Ma, W., Liu, D., Dai Y..Preparation of titanium carbide powders by carbothermal reduction of titania/charcoal at vacuum condition. International Journal of Refractory Metals and Hard Materials 28 (2010) 628-632.

[32.] Shin, H., Eun, J.H.. Titanium carbide nanocrystals synthesized from a metatitanic acid-sucrose precursor via a carbothermal reduction. Journal of Nanomaterials (2015) Article ID 469121, 11 pages.

[33.] Ren, X.T., Liu, Y.C., Chen, S.H., Hou, L.G., Wang, G.L., Teng, Y.C.. The Synthesis of TiC powders by carbothermal reduction method in vacuum. Advanced Materials Research 1064 (2015) 62-65. 
[34.] Yu, T., Deng, Y.H., Wang, L., Liu, R.L., Zhang, L.J., Tu, B., Zhao, D.Y..Ordered mesoporousnanocrystalline titaniumcarbide/carbon composites from in situ carbothermal reduction. Advanced Materials 19 (2007) 2301-2306.

[35.] Galevsky, G.V., Rudneva, V.V., Garbuzova, A.K., Valuev, D.V.. Titanium Carbide: Nanotechnology, Properties, Application. IOP Conference Series: Materials Science and Engineering 91 (2015) 012117

[36.] Pierson, H.O. Handbook of chemical vapor deposition (CVD), principles, technology, and applications. 2nd ed.; William Andrew Publishing: LLC Norwich, New York, U.S.A (1999) 1-506.

[37.] Ruppert, W., Schwedler, G.. Process for the production of titanium carbide coatings, U.S. Patent 2,962,388, Nov. 29, 1960.

[38.] Barth, S., Ramirez, F.H., Holmes, J.D., Rodriguez, A.R.. Synthesis and applications of one-dimensional semiconductors. Progress in Materials Science 55 (2010) 563-627.

[39.] Noel, M.S., Kovar, D.. Laser chemical vapor deposition of TiC on tantalum. Journal of Materials Science 37 (2002) 689-697.

[40.] Dariel, M.S., Aparicio, R., Anderson, T.J., Sacks, M.D.. CVD of TiC on refractory materials. Proceedings of 11th. International Conference on Chemical Vapor Deposition; Spear, K. and Cullen, G., Ed. Electrochemical Society Pennington U.S.A (1990) 659-669.

[41.] Stjernberg, K.G., Gass, H., Hintermann, H.E.. The rate of chemical vapor deposition of TiC. Thin Solid Films 40 (1977) 81-88.

[42.] Motojima, S., Mizatani, H..Preparation of TiC films by photochemical vapor deposition using a D2 lamp. Thin Solid Films 186 (1990) 17-20.

[43.] Knight, J.C., Page, T.F.. The fine-scale microstructure of thin hard TiN and TiC coatings on steels. Thin Solid Films 193 (1990) 431441.

[44.] Tong, L., Reddy, R.G.. Synthesis of titanium carbide nano-powders by thermal plasma. ScriptaMateriala 52 (2005) 1253-1258.

[45.] Kasimuthumaniyan, S., Singh, S.K. Jayasankar, K., Mohanta, K. Mandal, A.. An alternate approach to synthesize TiC powder through thermal plasma processing of titania rich slag. Ceramics International 42 (16) (2016) 18004-18011.

[46.] Preiss, H., Schierhorn, E., Brzezinka, K.W.. Synthesis of polymeric titanium and zirconium precursors and preparation of carbide fibers and films. Journal of Materials Chemistry 33 (1998) 4697 4706 .

[47.] Jiang, Z., Rhine, W.E.. Preparation of titanium diboride from titanium alkoxides and boron powder. Chemistry of Materials 4 (1992) 497-500.

[48.] Thorne K., Ting, S.J., Chu, C.J., Mackenzie, J.D., Getman, T.D. Hawthorne, M.F.. Synthesis of TiC via polymeric titanates: the preparation of fibers and thin films. Journal of Materials Science 27 (1992) 4406-4414.

[49.] Gallo, T., Greco, C., Peterson, C., Cambria, F.. Titanium carbide from carboxylic acid modified alkoxides. J. Burk, Materials Research Society Symposium Proceedings 271 (1992) 887-892.

[50.] Jiang, Z., Rhine, W.E.. Synthesis and pyrolysis of novel polymeric $\mathrm{TiC} / \mathrm{Al}_{2} \mathrm{O}_{3}, \mathrm{TN} / \mathrm{Al}_{2} \mathrm{O}_{3}$, and $\mathrm{AlN} / \mathrm{TiNnanocomposites.} \mathrm{Chemistry} \mathrm{of}$ Materials 6 (1994) 1080-1086.

[51.] Jiang, Z., Rhine, W.E.. Preparation of TiN and TiC from a Polymeric Precursor. Chemistry of Materials 3 (1991) 1132-1137.

[52.] Stanley, D.R., Birchall, J.D., Hyland, J.N.K., Thomas, L., Hodgetts, K..Carbothermal synthesis of binary (MX) and ternary (M1, M2X) Carbides, nitrides and borides from polymeric precursors. Journal of Materials Chemistry 2 (1992) 149-156.
[53.] Lang, H., Seyferth, D.. Pyrolysis of metallocene complexes $\left(n \mathrm{C}_{5} \mathrm{H}_{4} \mathrm{R}\right)_{2} \mathrm{MR}_{2}$ : an organometallic route to metal carbide (MC) materials $(\mathrm{M}=\mathrm{Ti}, \mathrm{Zr}, \mathrm{Hf})$. Applied Organometallic Chemistry 4 (1990) 599-604.

[54.] Gallo, T., Greco, C., Simms, B., Cambria, F.. In Covalent Ceramics. edited by Fischman, G.S., Spriggs, R.M., Aselage, T.L.. Materials Research Society Extention Ab. 23. Boston, U.S.A (1990) 29-32.

[55.] Ting, S.J., Chu, C.J., Limatta, E., Mackenzie, J.D., Getman, T., Hauthorne, M.F.. In Better Ceramics Through Chemistry IV, Edited by Zeninski, B.J.J., Brinker, C.J., Clark, D.E., Ulrich, D.R.. Materials Research Society Symposium Proceedings 180 (1990) 457-460.

[56.] Pierson, H.O.. Handbook of Refractory Carbides and Nitrides; Properties, Characteristics, Processing and Applications. William Andrew Publishing: Westwood, New Jersey, U.S.A. (1996) 1-360.

[57.] Grove, D.E., Gupta, U., Castleman, A.W.. Effect of carbon concentration on changing the morphology of titanium carbide nanoparticles from cubic to cubooctahedron. ACS Nano 4 (2010) 49-54.

[58.] Harbuck, D.D., Davidson, C.F., Monte, B.. Gas phase production of titanium nitride and carbide powders. The Journal of The Minerals, Metals \& Materials Society Metals 38 (1986) 47-50.

[59.] Goldschmidt, H.. German Patent 96,317, 1895.

[60.] Merzhanov, A.G.. In: Munir, Z.A., Holt, J.B.. Eds. Self-propagating high temperature synthesis: twenty years of search and finding in combustion and plasma synthesis of high-temperature materials. New York: VCH, U.S.A (1990).

[61.] Amosov, A.P., Borovinskaya, I.P., Merzhanov, A.G., Sychev, A.E. Regulation of particle size in SHS-produced powders: From single crystals to nanoparticles. IzvVysshUchebnZaved, TsvetnMetall 5 (2006) 9-22.

[62.] Moore, J.J., Feng, H.J.. Combustion synthesis of advanced materials: Part I. Reaction parameters. Progress in Materials Science 39 (1995) 243-273.

[63.] Marafona, J.D., Araujo, A...Influence of workpiece hardness on EDM performance. International Journal of Machine Tools and Manufacture 49 (2009) 744-748.

[64.] Nersisyan, H.H., Lee, J.H., Won, C.W.. Self-propagating hightemperature synthesis of nano-sized titanium carbide powder. Journal of Materials Research 17 (2002) 2859-2864.

[65.] Cochepin, B., Gauhtier, V., Vrel, D., Dubois, S..Cristal growth of TiC grains during SHS reactions. Journal of Crystal Growth 304 (2007) 481-486.

[66.] Zhang, M.X., Hu, Q.D., Huo, Y.Q., Huang, B., Li, JG.. Formation and growth mechanism of TiC terraces during self-propagating hightemperature synthesis from a Fe-Ti-C system. Journal of Crystal Growth 355 (2012) 140-144.

[67.] Ali-Rachedi, M., Ramdane, W., Vrel, D., Benaldjia, A., Langlois, P., Guerioune, M..The role of sintering additives on synthesis of cermets by auto-combustion. Powder Technology 197 (2010) 303308

[68.] Huque, Z., Azad, G.M.S.. Thermal conductivity effects on steady state propagation speed during self-propagating hightemperature synthesis of $\mathrm{Ti}+\mathrm{C}$ green compacts. Materials Science and Engineering: B 147 (2008) 19-26.

[69.] Subrahmanyan, J., Vijayakumar, M.. Self-propagating hightemperature synthesis. Journal of Materials Science 27 (1992) 6249-6273. 
[70.] Lee, D.W., Alexandrovskii, S., Kim, B.K.. Mg-thermal reduction of $\mathrm{TiCl}_{4}+\mathrm{C}_{\mathrm{x}} \mathrm{Cl}_{4}$ solution for producing ultrafine titanium carbide. Materials Chemistry and Physics 88 (2004) 23-26.

[71.] Lee, D.W., Alexandrovskii, S.V., Kim, B.K.. Novel synthesis of substoichiometric ultrafine titanium carbide. Materials Letters 58 (2004) 1471-1474

[72.] Lee, D.W., Yun, J.Y., Turaev, F.R., Kim, J.C., Kim, S.J.. Process optimization for production of ultrafine titanium carbonitride by magnesium reduction. Journal of the Ceramic Society of Japan 117 (2009) 600-603.

[73.] Lee, D.W., Baek, Y.K., Seo, I.S., Kim, J.N., Wang, J.P..Nanosized TiC and TiCN powders prepared by magensiothermic reduction. Journal of Nano Research 25 (2013) 122-127.

[74.] Lee, D.W., Ahnm, J.H., Kim, B.K.. Preparation of nanostructured titanium carbonitride particles by Mg-thermal reduction. Journal of Materials Research 20 (2005) 844-849.

[75.] Lee, D.W., Yu, J.H., Jang, T.. Properties of TiC and TiCN nanoparticles fabricated by a magnesium thermal reduction process. Solid State Phenomena 124 (2007) 1225-1228.

[76.] Lee, D.W., Alexandrovskii, S.V., Tolochko, O.V., Kim, D., Kim, B.K. Synthesis and kinetics for nanocrystalline titanium carbide upon metallothermic reduction of liquid chlorides. Glass Physics and Chemistry 31 (2005) 549-553.

[77.] Saal, K, Tätte, T, Tulp, I, Kink, I, Kurg, A, Mäeorg, U, Rinken, A Lõhmus, A. Sol-gel films for DNA microarray applications. Materials Letters 60 (2006) 1833-1838.

[78.] Cosentino, I.C., Muccillo, E.N.S., Muccillo, R.. Low-temperature sol-gel synthesis of singel-phase $\mathrm{ZrTiO}_{4}$ nanoparticals. Journal of Sol-Gel Science and Technology 47 (2006) 31-37.

[79.] Zhang, H., Li, F., Jia, Q., Ye, G.. Preparation of titanium carbide powders by sol-gel and microwave carbothermal reduction methods at low temperature. Journal of Sol-Gel Science and Technology 46 (2008) 217-222.

[80.] Preiss, H., Berger, L.M., Braun, M.. Formation of black glasses and silicon carbide from binary carbonaceous/silica hydrogels. Carbon 33 (1995) 1739-1746.

[81.] Raman, V., Bahl, O.P., Dhawan, U.. Synthesis of silicon carbide through the sol-gel process from different precursors. Journal of Materials Science 30 (1995) 2686-2693.

[82.] Benjamin, J.S.. Dispersion strengthened superalloys by mechanical alloying. Metallurgical Transactions 1 (1970) 29432951.

[83.] El-Eskandarany, M.S.. Synthesis of nanocrystalline titanium carbide alloy powders by mechanical solid state reaction. Metallurgical Transactions (a) 27 (1996) 2374-2382.

[84.] Razavi, M., Rahimipour, M.R., Mansoori, R..Synthesis of TiC $\mathrm{Al}_{2} \mathrm{O}_{3}$ nanocomposite powder from impure Ti chips, $\mathrm{Al}$ and carbon black by mechanical alloying. Journal of Alloys and Compounds 450 (2008) 463-467.

[85.] Razavi, M., Rahimipour, M.R., Rajabi-Zamani, A.H..Synthesis of nanocrystalline TiC powder from impure Ti chips via mechanical alloying. Journal of Alloys nand Compounds 436 (2007) 142-145.

[86.] Jia, H., Zhang, Z., Qi, Z., Liu, G., Bian, X..Formation of nanocrystalline TiC from titanium and different carbon sources by mechanical alloying. Journal of Alloys and Compounds 472 (2009) 97-103.

[87.] Cui, X.L., Cui, B.L.S., Wang, L., Qi, M.. Synthesis of titanium carbide powder from $\mathrm{TiO}_{2}$ and petroleum coke by reactive milling. Petroleum Science and Technology 20 (2002) 999-1007.
[88.] Zhu, X.K., Zhao, K.Y., Cheng, B.C., Lin, Q.S., Zhang, X.Q., Chen, T.L., Shu, Y.S., Yong, Q.L.. Fabrication of nanocrystalline TiC powder by high-energy ball milling. The Chinese Journal of Nonferrous Metals 11 (2001) 269-272.

[89.] Lohse, B.H., Calka, A., Wexler, D.. Synthesis of TiC by controlled ball milling of titanium and carbon. Journal of Materials Science 42 (2007) 669-675.

[90.] Razavi, M., Rahimipour, M.R., Kaboli, R..Synthesis of TiC nanocomposite powder from impure $\mathrm{TiO}_{2}$ and carbon black by mechanically activated sintering. Journal of Alloys and Compounds 460 (2008) 694-698.

[91.] Tang, W.M., Zheng, Z.X., Wu, W.C., Lu, J., Liu, J.W., Wang, J.M. Structural evolutions of mechanically alloyed and heat treated $\mathrm{Ti}_{50} \mathrm{C}_{50}$ and $\mathrm{Ti}_{33} \mathrm{~B}_{67}$ powders. Materials Chemistry and Physics 99 (2006) 144-149.

[92.] Ali, M., Basu, P..Mechanochemical synthesis of nanostructured titanium carbide from industrial Fe-Ti. Journal of Alloys and Compounds 491 (2010) 581-583.

[93.] Ghosh, B., Pradhan, S.K.. Microstructure characterization of nanocrystalline TiC synthesized by mechanical alloying. Materials Chemistry and Physics 120 (2010) 537-545.

[94.] El-Eskandarany, M.S., Konno, T.J., Sumiyama, K., Suzuki, K. Morphological and structural studies of mechanically alloyed $\mathrm{Ti}_{44} \mathrm{C}_{56}$ powders. Materials Science and Engineering: A 217 (1996) 265-268.

[95.] Viljus, M., Traksmaa, R., Letunovitš, S., Pirso, J..Synthesis of TiC by mechanical activation of powder components. International Powder Metallurgy Congress \& Exhibition EURO PM2001. European Powder Metallurgy Association: Nice, France (2001).

[96.] Zhu, X.K., Zhao, K.Y., Cheng, B.C., Lin, Q.S., Zhang, X.Q., Chen, T.L., $\mathrm{Su}$, Y.S.. Synthesis of nanocrystalline TiC powder by mechanical alloying. Materials Science and Engineering C 16 (2001) 103-105.

[97.] German, R.M.. Liquid Phase Sintering, Plenum Press, New York, U.S.A (1985).

[98.] Naidich, Y.V., Lavrinenko, I.A., Eremenko, V.N.. Capillary phenomena in the densification process during sintering in the presence of the liquid phase. International Journal of Powder Metallurgy 1 (1965) 41-48.

[99.] Heady, R.B., Cahn, J.W.. An analysis of capillary force in liquidphase sintering. Metallurgical Transactions 1 (1970) 185-189.

[100.] Cahn, J.W., Heady, R.B.. Analysis of capillary force in liquidphase sintering of jagged particles. Journal of the American Ceramic Society 53 (1970) 406-409.

[101.] Rahaman, M.N.. Ceramic processing, 1st Ed. ISBN 0-84937285-2. Wiley Online Library (2006).

[102.] Meredith, B., Milner, D.R.. The liquid-phase sintering of titanium carbide. Powder Metallurgy 19 (1976) 162-170.

[103.] Viljus, M., Pirso, J., Juhani, K., Letunovitš, S..Structure formation in Ti-C-Ni-Mo composites during reactive sintering. Materials Science 18 (2012) 62-65.

[104.] German, R.M., Suri, P., Park, S.J.. Review: Liquid phase sintering. Journal of Materials Science 44 (2009) 1-39.

[105.] Guillon, O., Gonzalez-Julian, J., Dargatz, B., Kessel, T. Schierning, G., Räthel, J., Herrmann, M.. Field assisted sintering technology/spark plasma sintering: Mechanisms, materials, and technology developments. Advanced Engineering Materials 16 (2014) 830-849.

[106.] Chuvildeev, V.N., Panov, D.V., Boldin, M.S., Nokhrina, A.V., Blagoveshchensky, Y.V., Sakharova, N.V., Shotin, S.V., Kotkov, 
D.N.. Structure and properties of advanced materials obtained by spark plasma sintering. ActaAstronautica 109 (2015) 172-176.

[107.] El-Eskandarany, M.S., Al-Hazza, A.. Mechanically induced self-propagating reaction and consequent consolidation for the production of fully dense nanocrystalline $\mathrm{Ti}_{55} \mathrm{C}_{45}$ bulk material. Materials Characterization 97 (2014) 92-100.

[108.] Cabrero, J., Audubert, F., Pailler, R..Fabrication and characterization of sintered TiC-SiC composites. Journal of the European Ceramic Society 31 (2011) 313-320.

[109.] Cheng, L., Xie, Z., Liu, G., Liu, W., Xue, W..Densification and mechanical properties of TiC by SPS-effects of holding time, sintering temperature and pressure condition. Journal of the European Ceramic Society 32 (2012) 3399-3406.

[110.] Li, Y., Katsuin, H., Goto, T.. Spark plasma sintering of TiC-ZrC composites. Ceramics International 41 (2015) 7103-7108.

[111.]Wang, L., Jiang, W., Chen, L.. Rapidly sintering nanosizedSiC particle reinforced $\mathrm{TiC}$ composites by the spark plasma sintering technique. Journal of Materials Science 39 (2004) 4515-4519.

[112.]Shinoki, F., Itoh, A.. Mass spectrometric analysis in RF reactive sputtering discharge. Japanese Journal of Applied Physics 2 (1974) 505-508.

[113.]Zega, B., Kornmann, M., Amiguet, J..Hard decorative TiN coatings by ion plating. Thin Solid Films 45 (1977) 577-582.

[114.]Ramalingam, S., Winer, W.O.. Reactively sputtered TiN coatings for tribological applications. Thin Solid Films 73 (1980) 267-274.

[115.]Igasaki, Y., Mitsuhashi, H., Azuma, K., Muto, T.. Structure and electrical properties of titanium nitride films. Japanese Journal of Applied Physics 17 (1978) 85-96.

[116.]Mullendore, A.W., Whitley, J.B., Mattox, D.M., Thermal fatigue testing of coatings for fusion reactor applications. Thin Solid Films 83 (1981) 79-85.

[117.]Donathamshetty, S., Damera, N.R., Jain, P.K.. Ultrasonic Cavitation Assisted Fabrication and Characterization A356 Metal Matrix Nanocomposite Reinforced with SiC, $\mathrm{B}_{4} \mathrm{C}$, CNTs. Asian International Journal of Science and Technology in Production and Manufacturing Engineering 2(2) (2009) 27-34.

[118.]George, P.M., Raghunath, B.K., Manocha, L.M., A.M. Warrier.. EDM machining of carbon-carbon composite-a Taguchi approach, Journal of Material Processing Technology 147 (2004) 66-71.

[119.]Hai, S., Wenli, G., Zhaohui, F., Zengh, L.. Processing, microstructure and tensile properties of nano-sized $\mathrm{Al}_{2} \mathrm{O}$ particle reinforced aluminum matrix composites. Materials and Design 36 (2012) 590-596.

\section{How to Cite This Article}

Mhadhbi, M. and Driss, M., Titanium carbide: Synthesis, properties and applications, Brilliant Engineering, 2 (2021), 1-11. https://doi.org/10.36937/ben.2021.002.001 